\title{
The Analysis of Theoretical-Methodological Approaches to the Study of Family Institution
}

\author{
Zaretkhan Khadzhi-Murzaevna Saralieva \\ Tatiana Nikolaevna Otdelkina
}

Lobachevsky State University of Nizhni Novgorod, (National Research University) Russia, 603000, Nizhni Novgorod, University lane, 7 ('Universitetsky Pereulok', 7)

Doi:10.5901/mjss.2015.v6n6s1p407

\begin{abstract}
The article deals with the complex analysis of approaches to the study of family institution. A review of main modern concepts and study theories of family items and problems is provided by both native and foreign authors. Besides, the article reveals and classifies the factors that influence on the system of marriage-family relationships in Russia and it provides the analysis of methodological approaches to the study of substitute family, as an institution of socialization for orphaned children and children without parental cares, the problems of which are quite urgent and need complex investigation.
\end{abstract}

Keywords: Family, patriarchal theory, system approach, functional approach, substitute family, social orphanhood.

\section{Introduction}

A family is a complex many-sided, multifunctional institution, the study of which cannot be carried out superficially in single-line direction. The family is an important primary institution for personality formation and development; its functions involve not only reproduction of population, but also upbringing of the younger generation in compliance with legal, sociocultural, ethic standards, accepted in the society. Globalization process, modernization of social relations, development of scientific-technological progress, changes in social-economic climate has a direct impact on the family institution and on the substantial aspect of childrearing.

On the one hand, it is possible to speak about the fact, that the family is an independent part of the society. On the other hand, it stays in close relations with the surrounding environment, and it is being transformed in compliance with the outside changes. The family is a kind of mirror, which reflects social-political and socio-cultural changes in the society, and also their positive or negative consequences. The family, being a structure-forming system of social life, concentrates all cardinal changes in the society.

It is necessary to mention, that the family also influences on the life of the society by means of fulfilling its main functions - reproduction of human kind and its upbringing, involving complex physical and mental-moral development. As the human society always requires reproduction of population, it maintains the social need in family, as the form of organization of children birth and socialization. These specific functions of the family stay the same even in case of different changes of the society, although the character of connection between the family and the society can be changed in the course of history (Kozlova, 2013, p.28).

The family takes a special place in the life of each person, as it is the family that helps the child, from the first years of life, to acquire social norms, the norms of human relations, main universal human values and worldview attitudes, thus forming his distant position in the system of interpersonal relations with surrounding people.

It is the family, where the fundamental bases are laid in the process of child's worldview formation and development, as well as determination of his social orienting points that play a pivotal role in his social development. Worldview orientation is mainly determined by the character of interpersonal relations between the parents and the child, the style of family upbringing, the requirements to the child in the process and upbringing, and the family structure.

Taking into consideration all above mentioned, it is necessary to note, that the study of family institution requires complex and many-sided approach, which is shown not only in the use of historically formed methods of its investigation, but also in the development of new theoretical and practical approaches and concepts, formed by means of new scientific views on the problems of family institution. 


\section{Theoretical-methodological Approaches to the Study of Family Institution}

\subsection{Historical retrospective of theoretical-methodological study of family institution}

Considering the historical retrospective of family study, it is possible to speak about the fact, that it takes its origin from the middle of the XIX century, when the family was considered as the initial micro-model of the society. Respectively, the society itself presented a model of the overgrown family, and social relations were considerably based on family ones. Primitive forms of marriage, their development and transformation in the process of historical development are reflected in the works of I.Ya. Bakhofen (1861), J. Mac-Lennan (1865), J. Lebbok (1870), L. Morgan (1877), F. Engels (1891), M.M. Kovalevsky (1895), Y. Koler (1896), M.O. Kosven (1953).

In time, the view of investigators shifts from the study of forms to the inner life activity of the family, which started to be considered as a specific social institution and became the further object of study. It is proved in the works of $E$. Vestermark (1891), who studied the relations of men and women in different tribes, as well as the incest taboo; in the analysis of gender relations by E. Dyurkgeim (1893) from the viewpoint of labor differentiation; in U. Ogborn (1922), who studied the process of retardation of material culture from the non-material (spiritual) culture, in consequence of which the family decays; in E. Berdgess (1926), who analyzed family-marriage relations in the process of urbanization and industrialization of the society, and also considered the family as an institution of personality formation. Great attention is paid to the process of spectrum narrowing of functions, fulfilled by the families due to their historical transition to the other social institutions.

In the XIX century, the investigations, devoted to the study of family, as a small initial group, having special history of origin, functioning and stages of life activity are carried out. The founder of family study from the empirical viewpoint, in particular, using the monographic method, is F. Le Ple (1855), whose ideas anticipated the life cycle concept of the family, as a small group.

The family, as a social-psychological group, was studied by Z. Freud (1901; 1905,1909 1920), U. Thomas and F. Znanetsky (1918-1921), Zh. Piazhe (1932), Ch. Kuli (1956), U. James (1991). They considered the interrelation of family and society on the level of primary, interpersonal relations.

\subsection{Russian retrospective of theoretical-methodological study of family-marriage institution}

The analysis of native studies of family-marriage problems provides an opportunity to distinguish three historical stages:

1. The first stage is from the middle of the XIX century to the 1920 of the XX century. In this period, the family was one of the general problems of sociology and did not have the status of individual substantive branch. However, the gap, due to the absence of the specific approach to family study, was closed by means of investigations under psychology and pedagogics, history and philosophy, ethnography and culturology. On this stage, the contribution to the family-marriage studies in Russia, was made by D.N. Dubakin (1880), P.A. Sorokin (1911; 1916), M. M. Kovalevsky (1914).

2. The second stage starts from the beginning of 1920 to the 1960 of the $X X$ century. At this stage, the analysis of family-marriage problems is presented in the works of K. N. Kovalev (1931), A. M. Kollontay $(1918,1921)$, A. V. Lunacharsky (1927), E. A. Preobrazhensky (1923), L.D. Trotsky (1923), devoted to the discussion about the development of proletarian "family unit".

3. The third stage is from 1960 up to present times. The sociology of family and marriage becomes an independent branch of sociological knowledge. The founders of different modern scientific approaches to the study of family problems were A. G. Kharchev (1964; 1968), M. S. Matsovsky (1989), A. I. Antonov (1980). (Osoheeva, 2007, p. 5)

S.I. Golod analyzes the modern state of the family-marriage institution and the history of its development; based on its content, he develops the concept of ideal historical types of monogamy (patriarchal, child-centrist and marriage), the replacement of which provides the historical changes in family functioning. The role of such social-psychological values of the family, as intimacy and self-sustainment, are considered separately (Golod, 1998).

\subsection{System and functional approaches to the study of family institution}

As the family is a complex component of the society, there are a lot of different approaches to its study, where the family is considered from different angles, and different aspects are distinguished. Thus, for instance, from the perspective of system approach, the family is determined as a group of people, which is united by commonplace of living, joint 
household, and, mainly, cooperation. According to this viewpoint, the inner processes are directly subject to system properties, as they are, and do not depend on the wishes and intentions of family members, involved to this system, as the activity, decisions and behavior of system members have the secondary meaning, and they are subject to the laws of life activity of family system.

According to the basic idea of system approach, the family is a social system, namely, the complex of structural elements and their properties, which are in dynamic relations with each other. It presupposes, that the analysis of the family shall provide the study of its structural elements and processes, which are interdependent and condition each other, as well as the study of system features of the family, namely, its connections with inside and outside systems, levels of organization and laws of its functioning and changing. (Antonov and Medkov, 2006, p. 35)

In this context, the family system shall be flexible, as it tends to stability from the inside, and it needs updating under the historical development from the outside (Gurko, 2010, p. 94).

From the perspective of functional approach, the family is considered as the institution, which task is to fulfill main functions - reproduction, socialization, concern, protection and emotional support, social-status function (provision of definite social status to family members, reproduction of social structure), household-economic function (involves family life arrangement, formation and spending of home budget). In the context of this approach, it is possible to speak about family study from the viewpoint of its life activity, namely the spectrum of family functions and their fulfillment are studied. In the course of time the number of functions increases or decreases. It is also possible to speak about the fact, that the reasons and tendencies, influencing on their study, are analyzed under this approach.

This approach is aimed at the search of the general, that is peculiar of different types of families in the course of their development history, but it concentrates attention not only on family universalism, on historical forms of implementation of family "idea", but mainly on the family-home life itself, on socio-cultural functions of the family, as a social phenomenon, and on interrelations of socio-cultural roles, connected with marriage, kinship and parenthood. (Antonov and Medkov, 2006, p. 44)

\subsection{Main approaches to determination of "family" category}

The analysis of definitions of the family by different authors shows the shift of accents in the course of investigation. For instance, A. I. Antonov determines clear boundaries of the family, but he does not take into consideration the diversity of forms of family life, considering it, mainly, as a social institution. The definition of family by S. I. Golod reflects the diversity of forms of family relations, blurring of lines of the family, which is mainly presented as not the social institution, but as the small social group.

Foreign authors mainly consider the family as the small social group. J. Merdok (2003) and D. Popenoe (1996) involves adopted children and dependants to their definitions of family structure, what is absent in the definitions of Russian authors, where "children" are interpreted exclusively as blooded. It is necessary to note, that some authors define the family as a group of people, united either by blood relationship, or by intimate, sexual relationships. In this case, the pair without registered marriage and common family activity would be considered as the family. This viewpoint is not shared by such Russian authors, as M. S. Matskovsky, A. G. Kharchev, A. I. Antonov.

However, depending on the fact, what approach is used to study the family and what is central for the investigator, it is possible to speak about different definitions of the "family". T. A. Gurko (1995) considers: "Today, obviously, it is more reasonable to speak not about "the family", where it is difficult to involve all possible variations in terms of the definite culture, but about the families. The answer to the question, what the family is, can constitute either in narrowing of notion, as supposed by some foreign scientists, and in considering only such communities, where the dependent members exist (non-adults, invalids or elderly people) to be the family, or it is necessary to distinguish different types of families as the small groups of special kind. The last is of extreme importance in empiric investigations, including the intercultural ones".

\subsection{The study of the institution under the transformation of the society}

Modern family differs significantly from the family of previous years. As it was mentioned before, there is the transformation of not only family functions, but also of its forms, structure, character of interfamily relations, and also functional division of different spheres of activity. In modern sociological theory, it is possible to distinguish two main approaches to the theoretical understanding of transformation process of the family institution. Under the first approach, the modern family is considered as natural modification of the traditional family in the process of historical transition from the industrial to postindustrial society. M. S. Matskovsky, S. I. Golod, A. G. Vishnevsky (1982) perceive the changes of the family institution mainly as a positive process of "pluralization" of family forms, when new alternative family structures 
appear on the fragments of old traditional family.

The second approach is diametric, and it states, that the modern family institution is in critical stage of development, which will result in the degradation of society in whole. A. I. Antonov, V. M. Medkov, V. A. Borisov (1990), S. S. Sedelnikov $(1989,1992)$ consider the family changes as an expression of global crisis of family way of life, the decay of family as a social institution. At that, the negative phenomena, connected with non-fulfillment of main functions of the family, are interpreted as the expression of not just crisis of one family institution, but as the value-conscious crisis of the whole society. A. I. Antonov understands the crisis as "the value-conscious conflict of the personality and the society relatively childbirth and children socialization, resulting in non-fulfillment of reproductive and socialization functions by the family, accompanied by the weakening of the family, as the union of family members (nucleation process), the union of parents and children (the process of conjugation and devaluation of family, children, parenthood), the union of partners (the process of individualization, autonomation), the weakening of trinity of kinship-parenthood-marriage due to disappearance of family production, joint activity of parents and children (the process of replacement of family-centrism by egocentrism)" (Antonov and Medkov, 2006, p. 111 - 112).

\subsection{Factors, that influence on the system of family-marriage relations in Russia}

Under modern concepts, it is possible to distinguish the factors, that influence on the system of family-marriage relations in Russia:

1. Social-economic factors involve, first of all, the events, that take place during the XX century, namely, the first world and civil war, New Economic Policy, collectivization. These milestones caused the changes of familymarriage relations and "exploded" the reputation of patriarchal family. As a result, in total, it caused such processes, as migration of families to the cities $\rightarrow$ change of family way of life, what, in its turn, involved women to labor relationships for family welfare $\rightarrow$ the level of birthrate recessed, resulting in the increase of families with few number of children. (Volkov, 1999, p. 42)

2. Political factor. The policy of totalitarian state influenced greatly on the changes of family-marriage relations. It is this time, when the freedom of divorces was limited, the tax on childlessness was introduced and the abortions were prohibited.

3. Socio-cultural factor. This refers to the change of social relations, together with which the women and the men get the equal rights. Children become the obstruction for the woman in her social realization (the increase of families with little number of children); in this connection, there appear the fostering institutions for children of preschool age, disrupting the upbringing and moral function of the family. (Volkov, 1999, p. 46)

4. Social-demographic factor. The system of family-marriage relations was influenced by the development of medicine that provided an opportunity to control the childbearing. Apart from this, the increase of schooling years also influenced: it caused the distribution of such phenomenon, as common-law marriage and increase of age, when creating the family, i.e. the family began to be created later. (Golod, 1998, p. 190)

5. The change of historical types of the family (patriarchal, child-centrist, marriage). S.I. Golod mentions that the system of family-marriage relations is influenced by the type of family, dominating in the society. He explains the equality of man and woman in the family, planning of childbearing and increase of families with the little number of families by the predominance of child-centrist type, characterized by these features (Golod, 1998, p. 118 - 159); A.R. Mikheeva (2001) determines the peculiarities of interfamily relations in dependence on the predominant type of family.

6. The replacement of some family functions by the state. The state fulfils many functions of the family in modern world. It decreases the level of parents' responsibility and family cohesion. Let us add that at present, a woman can be able to raise one child, getting the state aid, what results in the increase of this category of families (Antonov and Medkov, 2006, p. 69).

\subsection{Young family}

Separate place in the investigations of modern family is taken by the study of the young family, which is distinguished as an object of target-specific social policy of the state. The works of Zh. Chernova, L. Shpakovskaya (2010), N. N. Azisova (2002), A. K. Dzakgoev (2000), I. G. Neudachnina (2003), Yu. N. Oleynik (1989), E. P. Vasilyev (2007), V. V. Tikhomirov (2010), B. R. Osokheeva (2007), T. K. Rostovskaya (2013) provide the analysis of status of modern young family, its social status in conditions of modern transformation of Russian society, and gender analysis of family-marriage relations of partners, the levels of their compatibility and distribution of roles. The item about problems and functioning of the young 
family in the process of its life activity, about the state support is raised in the works of L. S. Rzhanitsyna (2011), E. V. Isakova (2010), T. A. Gurko (2008). It is necessary to mention, that the results of study of young family problems are mainly reflected in dissertations, involving both the analysis of regulatory bases in the sphere of young families state support control, and interfamily life activity from the perspective of gender and social-psychological approaches.

\subsection{Social work with different categories of families}

In conditions of appearance and increase of maternal, paternal, substitution and other types of families, there is a necessity to develop not only the system of state support for different categories of families (V. M. Zakirova (2004), A. N. Voronov (2009), A. O. Kurbangaleeva (2008), G. V. Sabitova (2007)), but also the system of social work with them, involving the training of specialists of this sphere (V. N. Gurov (2002), V. S. Torokhtiy (2000), V. V. Matveeva (2007), A. M. Panov (2006), E. I. Kholostova (2007), E. I. Tyurina, N. Yu. Kuchukova, E. A. Pentsova (2009), L. A. Saenko (2007)). Apart from that, the abovementioned authors consider the peculiarities of different types of families, their functioning and life activity. The special place under the social work with different categories and types of families is taken by the psychological-pedagogical approach to the maintenance and support of families, which is reflected in the works of $L$. $Z$. Galeeva (2008), L. V. Kartseva (2010), L. S. Alekseeva (1998) and others. A complex sociological approach to the study of peculiarities of social work with the family, involving demographic, juridical, empirical materials, as well the experience of other countries in this sphere, is reflected in the works of Z. Kh. Saralieva (2003); separate aspects are presented in the works of N. S. Stepashov (1997), O. N. Bezrukova (2007), T. S. Zubkova, N. V. Timoshina (2003).

The problems of social ill-being and constantly growing level of social orphanhood and its preventive measures are described in the works of I. I. Osipova (2008), L. S. Alekseeva (2005), S. I. Golod (1998), S. A. Sorokin (1999), M. O. Dubrovsky, V. K. Zaretsky, V. N. Oslon, A. B. Kholmogorova (2002), E. R. Yarskaya-Smirnova, G. A. Teper, N. V. Grek (2008), E. B. Breeva (2004). These authors, alongside with I. F. Dementyeva (2001), in their works substantiate the thesis about more smooth socialization and successful development of the child in native or substitute family, than in conditions of orphan. The analysis of problems of orphaned children and children without parental care, as well as negative sides of their upbringing in orphans, are reflected in the works of M. S. Astoyants (5), L. Ezhova, E. M. Poretskina (27) and others.

\subsection{The study of substitute family as a special category of the family institution}

The historical aspect of development of substitute family was analyzed in the works of S. V. Bakhrushin, G. N. Maksimov, N. V. Yablokov. At modern stage, the problems of theory and history of social orphanhood in Russia are developed in the works of L. V. Badya, M. V. Firsov, E. I. Kholostova, N. N. Chernetsov (Smirnova, 2013, p.5).

The problems of family organization forms of children without parental care are considered in the works of $Z$. I. Voronin (2003), Zh. A. Zakharov (2008), A. M. Nechaev (1994), L. Yu. Mikheev (2004), V. N. Oslon (2006), V. G. Krasnov (2011), L. Vilyaste and G. V. Semya (2007).

Frequently, the competencies and inner resources of prospective foster parents are not enough to create the socially-happy substitute family, because of absence of special knowledge in pedagogic and psychology of orphaned children and children without parental care. In this context, the development of maintenance services for substitute families and training of specialists to help them is one of the most important directions of family policy. These problems, as well as the problems of adaptation of upbringing of orphaned children, are presented in the works of N. P. Ivanova (2008), N. A. Khrustalkova (2006), Zh. A. Zakharova (2008), N. L. Bolshakova (2008), T. Kurasov (2010), N. Polomarets (2009), V. N. Oslon (2009), N. P. Ivanov (2008). The works of T.Z. Kozlova (2013) deals with the analysis of formation of parents' personality of orphaned children.

Concerning professional and "non-professional" forms of substitute family, they are reflected not only in some publications and study materials (N. A. Rybakov (2002), O. V. Besschetnov (2009), T. A. Gurko and V. B. Taseev (2007), O. V. Neverov (2010), L. Oliferenko (2003), N. M. Iovchuk, E. Morozov, A. Shcherbakov (2004), O. B. Zernitsky (2002)), but also in dissertations: R. A. O. Shukurov, (Belgorod) (2004); V. A. Tsvetkov, (Tomsk) (2005), V. V. Skatov (Saratov), E. R. Alekseev (Moscow).

The most widespread form of family organization for orphaned children and children without parental care is the foster home. The problems of psychological-pedagogical adaptation of children and parents in foster home and its functioning are reflected in the works of A. G. Rudov (2010), N. P. Voznyuk (2009), E. Bayer (2009), E. N. Denisova (2007).

In sociological literature, the problems and types of family organization for orphaned children and children without 
parental care are reflected in scientific thesis and articles of both information-description and investigative character. In whole, the authors do not use complex approach in the analysis of forms of substitute families, making the problem of family sociology very urgent.

\section{Conclusion}

The executed analysis of theoretical-methodological approaches to the study of family institution proves that the important principle of its modern study is the complex character. As a result of perception of historical evolution of views on the study of family institution, key theoretical concepts were revealed; they allow describing the types of familymarriage unions and their inner life activity from different angles. The analysis of historical development of these concepts provided an opportunity to determine the diversity of methodological approaches to the family and marriage study. The following conclusion is based on the study of modern concepts: the transformation of scientific views on family is determined on the basis of mutual influence of outside factors and inner content. Besides, not only foreign investigations in this sphere were structured, but also Russian experience of family study was systematized. It allowed revealing the specificity of factors, influencing on the system of family-marriage relations, typical of Russian society, and determining the main directions of social work with different categories of families, which are especially urgent in scientific sociological field.

It is necessary to note, that not all types of family-marriage relations and peculiarities of their investigation were analyzed by the authors. It is one of the perspectives of study of this topic, as, when determining the main approaches to their investigation, we can evaluate the advantages and disadvantages of these investigation methods for the most qualitative and complex revelation of problems of different family categories, their solution and further prevention. The authors describe the system and functional approach to the family institution study, predominant in sociological field, what presents the incomplete picture of scientific views, which requires further investigation.

\section{References}

Azisova, N. N. (2002). Social status of the young family in modern Russia (Unpublished doctoral dissertation). Mordovian State University, Saransk.

Alekseeva, L. S. (2005). Half-way house - structural subdivision of the Center of Family and Children Social Support: methodological recommendations on activity arrangement (pp. 128). Moscow.

Alekseeva, L. S. (1998). Work with the family in the care-giving institutions: social-psychological aspect. Family in Russia, 3/4, 112-124.

Antonov, A. I. (1996). Sociology of the family (pp. 304). Moscow: MSU; International Business and Management University (Karich Brothers).

Astoyants, M. S. (2006). Orphaned children: the analysis of life practices in the residential care home. The experience of overt observation. Sociological Investigations, 3, 54-63.

Bayer, E. (2009). Foster home for orphaned children. Social Pedagogics, 1, 123-128.

Bezrukova, O. N. (2007). Families in St. Petersburg: the status and perspectives of social works (following social research) (pp: 113). St. Petersburg.

Besschetnova, O. V. (2009). Foster home as an implementation of constitutional right of orphaned children to family upbringing. Tomsk State Pedagogical University, 7, 71-75.

Bolshakova, L. N. (2008). Adaptation of children in foster home. Family Psychology and Family Therapy, 4, 28-40.

Bolshakova, L. N. (2008). The substitute families need help. Orphan Asylum, 3, 30-33.

Breeva, E. B. (2004). Social orphanhood. The experience of sociological examination. Sociological Investigations, 4, 44-50.

Vasilyev, E. P. (2007). The status of young family in modern Russian society (Unpublished doctoral dissertation). Kazan: The Kazan State University.

Voznyuk, N. P. (2009). Modeling of successful foster home. Social Pedagogics, 6, 107-115.

Volkov, A. G. (1999). Why have the Russian family changed? Family in Russia, 1-2, 40-53.

Voronina, Z. I. (2003). Legal forms of upbringing of children without parental care (Unpublished doctoral dissertation). St. Petersburg.

Voronov, A. G. (2009). State policy of the Russian Federation in the system of social maintenance of the family and children (Unpublished doctoral dissertation). St. Petersburg State University.

Galeeva, L. Z. (2008). Psychological-pedagogical innovations in the work with modern family. Social Service Worker, 4, 27-36.

Golod, S. I. (1998). Family and marriage: historical-sociological analysis (pp. 272). St. Petersburg: Petropolis. ISBN 5-86708-113-3.

Gurko, T. A. (2007). The experience of organization of foster homes in Samara District. SOTSIS, 9, 78-85.

Gurko, T. A. (2008). Russia: social policy in relation to young parents. Vdast, 6, 10-14.

Gurko, T. A. (2010). Theoretical approaches to family study (pp. 94). Moscow: The Institute of Sociology RAS.

Gurko, T. A. (1995). Transformation of the modern family institution. Sociological Investigations, 10, 96.

Gurov, V. N. (2002). Social work of school with the family (pp. 191). Moscow: Pedagogical Community of Russia. 
Dzakgoev, A. K. (2000). Young family in modern conditions: at the materials of the Republic of North Ossetia-Alania (Unpublished doctoral dissertation). Moscow: Social Technological Institute.

Dementyeva, I. F. (2001). Negative factors of children upbringing in single-parent family. SOTSIS, 11, 108-113.

Denisova, E. N. (2007). The first year of life of the foster home. Orphan Asylum, 4, 13-19.

Ezhova, L. (2004). The forms of upbringing of orphaned children, alternative to the state ones: Russian discourse and practice. Social Policy, 2, 203-227.

Zakirova, V.M. (2004). Family and social policy: to the problem of definition of family welfare. Social Policy and Sociology, 2, 188-196.

Zaretsky, M.O. (2002). The ways to solve the orphanhood problem in Russia. The Problems of Psychology, 16-26.

Zakharova, Zh. (2005). Upbringing of children in substitute families. Social Work, 1, 35-39.

Zakharova, Zh. (2008). Training of substitute parents to the new role. Social Pedagogics, 2, 34-38.

Zernitsky, O. B. (2002). Motivation of adoption and peculiarities of parent positions in families with adopted children. A Reporter of Psychosocial and Correction-Rehabilitation Work, 1, 45-50.

Zubkova, T. S. \& Timoshina, N. V. (2003). Organization and content of work on social protection of women, children and family: a school guide for the institutes of vocational secondary education (pp. 221). Moscow: Academy.

Ivanova, N. P. (2008). Substitute family. The tasks for specialists. Orphan Asylum, 1, 10-12.

Ivanova, N. P. (2008). Social adaptation of children in substitute family. Family in Russia, 2, 59-65.

lovchuk, N. (2004). The support of orphaned children, grown up in families. Social Pedagogics, 2, 82-86.

Isakova, E. V. Main problems of young families and the analysis of the existing ways of their solution. Retrieved April 7, 2015, from http://ecsocman.hse.ru/text/33373537/

Kvartseva, L. V. (2010). Psychology and pedagogics of social work with family: study guide (pp. 224). Moscow: Dashkov and Co.

Krasnova, V. G. (2011). To the problem of effectiveness of life organization of orphaned children. Psychology and Pedagogics, 3(15), 74-79.

Kozlova, T. Z. (2013). Inter-generational relations in primary family of foster parents. Human Capital, 3, 23-28.

Kurasova, T. (2010). Foster home: complex social-pedagogical support. Social Pedagogics in Russia, 1, 14-18.

Kurbangaleeva, O. A. (2008). Maternity capital: how to get? Business Accounts, 7, 39-44.

Matveeva, V. V. (2007). Sociology of conflict in the strategy of social work with family. Native Journal of Social Work, 4, 36-42.

Mikheeva, A. R. (2012). Transformation vectors of family relations: the analysis of historical and modern empirical studies in terms of structural-genetic approach (pp. 48). Novosibirsk: IEOPP SO RAS. 48 c.

Mikheeva, L. Yu. (2004). Guardianship and custody: theory and practice (pp. 368). Moscow: Wolters Kluwer. ISBN 5-466-00035-3.

Neverova, O. V. (2010). Models of orphaned children in context of social changes. Native Journal of Social Work, 5, 45-53.

Neudachina, I. G. (2003). Modern Russian young family: gender analysis (Unpublished doctoral dissertation). Yekaterinburg: The Urals State University named after A.M. Gorky.

Nechaeva, A. M. (1994). Protection of orphaned children in Russia (history and contemporaneity) (pp. 176). Moscow: Dom. ISBN 546138-122-2.

Oleynik, Yu. N. (1989). The study of compatibility levels in young family. Psychological Journal, 2, 59-65.

Oliferenko, L. (2003). Foster home is the protection institution of childhood. Social Pedagogics, 2, 77-88.

Osipova, I. I. (2008). The phenomenon of social orphanhood in modern Russia. Social pedagogics: theory, practice, perspectives (pp. 234-241). Moscow: RSSU.

Oslon, V. N. (2001). Substitute professional family as one of the models to solve the orphanhood problem in Russia. The Problems of Psychology, 3, 79-90.

Oslon, V. N. (2006). Life organization of orphaned children: a professional substitute family (pp. 368). Moscow: Genesis. ISBN 5-98563055-2.

Oslon, V. N. (2009). To the concept of psychological support of the substitute family. Psychological Science and Education, 3, 44-52.

Osokheeva, B. R. (2007). Modern young family: transformation processes and stabilization factors (Unpublished doctoral dissertation). Ulan-Ude: The Buryat State University.

Panov, A. M. (2006). Conceptual and scientific-methodological bases for the centers of social support of the family and children. Social Services, 2, 14-36.

Polomarets, N. (2009). Maintenance service and a school for foster parents. Social Pedagogics in Russia, 6, 50-52.

Rzhanitsyna, L. S. (2011). Young families with children: who are they, how do they live and what do they want? Sociological Studies, 3 , 85-94.

Rostovskaya, T. K. (2013). The processes of institutionalization of the young family. The Reporter of Higher Education Institutions. Povolzhskiy Region. Social Sciences, 2 (26), 84-90.

Rudov, A. G. (2010). How to prepare a house for the adopted child. Social Pedagogics in Russia, 2, 29-32.

Rybakova, N. A. (2002). Foster care and foster parents. A Reporter of Psychosocial and Correction-Rehabilitation Work, 3, 44-52.

Sabitova, G. V. (2007). Legislative guarantee of social-pedagogical support of families with children in Russia. Native Journal of Social Work, 3, 26-35.

Saenko, L. A. (2007). Training of future social pedagogues to work with unemployed families. Higher Education Today, 8, 69-70.

Saralieva, Z. Kh. (2003). A family is a client of social work: study guide (pp. 287). Nizhny Novgorod.

Semya, G. V. (2007). Family forms of support of orphaned children and children without parental care. Social Pedagogics, 1, 32-40.

Smirnova, A. S. (2013). Social welfare of foster home: sociological analysis (Unpublished doctoral dissertation). Yekaterinburg. 
Sorokin, S. A. (1999). Russian family and three draft laws on its protection. (pp. 167). Moscow: Economy. ISBN 5282019760.

Stepashov, N. S. (1997). Methodological bases to determine the criteria of effectiveness of social work, in keeping with the purposes and tasks of modern family policy. Study guide for social workers (pp. 20). Kursk: KSMU.

Tikhomirova, V. V. (2010). Social well-being and social orientations of the young family. Sociological Studies, 2, 118-124.

Torokhty, V. S. (2000). The bases of psychological-pedagogical provision of social work with the family: study guide for students of sociological faculties and universities (pp. 238). Moscow: Moscow State Social University.

Tyurina, E. I. (2009). Social work with the family and children (pp. 288). Moscow: Academy. ISBN 978-5-7695-5703-3.

Kholostova, E. I. (2007). Social work with the family: study guide (pp. 211). Moscow: Dashkov and Co.

Khrustalkova, N. A. (2006). Upbringing of children in professional-substitute families. Higher Education Today, 11, 34-36.

Khrustalkova, N. A. (2006). Social Pedagogue: the help to professional-substitute family. Higher Education in Russia, 11, 175-176.

Khrustalkova, N. A. (2006). Organizational-pedagogical work of social pedagogues with the professional-substitute family. Innovations in Education, 6, 80-100.

Shukurov, R. A. O. (2004). Foster home on family law of Russia (Unpublished doctoral dissertation). Belgorod: Belgorod State University.

Tsvetkov, V. A. (2005). Foster home as a form to suport children without parental care, in keeping with the legislation of Russian Federation (Unpublished doctoral dissertation). Omsk: Tomsk State University.

Chernova, Zh. V. (2010). Young adults: marriage, partnership and parenthood. Discursive prescripts and practices in modern Russia. Sociological Studies, 3, 19-43.

Yarskaya-Smirnova, E. R. (2008). Dump kids: a problem of prevention of early social orphanhood. A Woman in Russian Society, 3, 3148. 